\title{
NOTES ON AUSTRALIAN EARTHWORMS. Part III.
}

\author{
By J. J. Fletcher, M.A., B.Sc.
}

Since my last paper appeared I have been able to see the papers of H. Ude (1) and Dr. Rosa (2). The former mentions (pp. 133 and 134) his having received from Sydney, N.S.W., specimens of Allolobophora foetida Sav., and A. turgida Eisen. (3) The latter points out that the species which, for lack of opportunity of consulting any of the papers in which it has been described, I at first supposed was the Lumbricus Novce-Hollandice of Kinberg, and which, subsequently finding this not to be the case, from its wide distribution in this colony I supposed was indigenous, and referred to it in my second paper as A. australiensis n. sp., is the same as one of these mentioned above by Ude, namely the European species A. turgida, Eisen. Therefore, if we except Kinberg's doubtful species, no indigenous anteclitellian worms are known as yet from Australia, the three species of such worms which have already become established in varions parts having been introduced. Of these, $A$. turgida is spreading with extraordinary rapidity and has completely outstripped the other two. Indeed taking into account its feebler powers of locomotion, and that it was not intentionally introduced, the rapid distribution of this worm is as remarkable as that of any of our interlopers. In this colony I have examples of this worm from almost every locality from which $\mathrm{I}$ have obtained or received earthworms, with the exception of a few favoured spots

(1) " Ueber die Rückenporen der Terricolen Oligochæten," in Zeitschrift für wiss. Zool. Band XLIII, 1885, p. 87.

(2) "I Lumbricidi Anteclitelliani in Australia," in Bol. dei Musei di Zool. \&c. R. Universita di Torino, Vol. I, No. 18.

(3) Incorrectly referred to as Allobophora in my two previous papers. 
like Burrawang, which are distant from towns, and where so little is done in the way of æsthetic gardening that few opportunities have presented themselves to this species of spreading to them. It is common on the Blue Mts. at Springwood and the Valley. It has crossed the Dividing Range and flourishes in the Mudgee District. It is very abundant in the Hunter River District on the north, as in the southern districts it is also at Braidwood and Wagga Wagga. It has long since escaped from gardens and has taken to bush land which has never been cultivated. And where it has become established my experience is that the worms of this species are more abundant than indigenous ones. It has also established itself in the other colonies, as recently Mr. Froggatt brought me specimens of it from Sandhurst, Victoria, and Professor Rennie has also sent me a number of examples of it from his garden at Adelaide. Ude states that he has also received specimens of it from "Milwaukee U.S.A. and Mexico. It is possibly the worm referred to by an American writer in "Nature" (1884, p. 503), extracts from whose letter are quoted in a footnote on p. 528 of my first paper. On the occasion of my last visit to Mount Wilson, though I have never met with anteclitellian worms there before, on turning over a patch of cowdung by the road side on the sandstone country and at some distance from cultivated land, Mr. Cox noticed thirty or forty small worms which may also belong to this species. I took ten specimens at random, and though the largest of them (in spirit) is only $36 \mathrm{~mm}$. long, they all have girdles commencing with $\mathrm{xxv}$ or $\mathrm{xxVI}$ and including $\mathrm{xxxI}$ or XXXII (in one case XXIV-XxviII).

The other two species of Allolobophora which occur here do not seem to have spread beyond the gardens of the Australian capitals. Ude received examples of $A$. foetida Sav. from New Zealand and Sydney. All the examples I have seen yet are from Sydney or Melbourne gardens, from the latter locality brought me by Mr. Froggatt.

Of the third species I have seen examples only from the Hon. William Macleay's garden at Elizabeth Bay where it is abundant, 
from one of the Sydney nurseries, and from one of the enclosures in Hyde Park. It does not agree exactly with any of the descriptions I can find, but seems to come nearest the A. profuga of Rosa.

From two of these gardens I have numerous specimens of a species of Perichæta ( $P$. peregrina) which is supposed to have come from the Mauritius, and which I have already described. In this paper I describe another possibly introduced species only known to me at present from specimens from Mr. Macleay's garden in Sydney, from some which Professor Rennie has sent me from Adelaide, and from Mulwala. It differs from any other worm I have yet seen from Australia in having the male pores on the seventeenth segment.

In what follows I give descriptions of ten new species of indigenous worms, as before taking note of the more prominent anatomical characters, but, in the hope of acquiring additional types, leaving the consideration of morphological details until I come to revise the whole. Of these all but two belong to the genus Perichceta the most abundant Australian type, of which I have previously described several species. They comprise species from N. Queensland, New South Wales, and South Australia, and one of them ( $P$. canaliculata) collected by Mr. Froggatt in N. Queensland is especially interesting because it is intra-clitellian. Of another species from Mt. Wilson, which I here describe, all the specimens obtained were postclitellian with a solitary exception which was intraclitellian. These two species therefore are of considerable interest because they add additional strength to the view put forward by Beddard, who has met with a similar experience to mine, in the case of the species of Acanthodrilus, that while Perrier's distinction between anteclitellian and the other two groups into which he has subdivided earthworms is valid enough, his division between the intraclitellian and postclitellian groups is too artificial to be permanently retained, even though in the present state of our knowledge of these animals it may be convenient for the time being to make use of it. 
The remaining two species are postclitellian, with eight rows of setæ. One from the Hunter and Hawkesbury districts is a new type for which is established the new genus Perissogaster, characterised by the presence of three gizzards, but it differ's fundamentally from Benham's recently instituted genus Trigaster in the characters of the generative organs.

The other species is an interesting little worm I have recently found at Mt. Wilson, in which I have as yet been unable to find either gizzard or spermathecæ. As I wish to avoid multiplying genera 1 provisionally refer it to the genus Cryptodrilus, which at present consists of a somewhat heterogeneous collection of species whose common characters so far appear to be that they are postclitellian ; have eight rows of setæ, not in pairs, and frequently at considerable intervals apart; a single (or no) gizzard: and that they have the male pores opening on the eighteenth segment.

I have to acknowledge the valuable assistance $I$ have received in various quarters. For entirely new material, or for the opportunity of obtaining it I have especially to thank Mrs. Windeyer of Raymond Terrace, the Hon. W. Macleay, Rev. K. A. Corner, Mr. J. D. Cox, Mr. A. G. Hamilton, Professor Rennie, Dr. E. C. Stirling, Dr. E. P. Ramsay, Mr. Masters, and Mr. T. G. Sloane. Not less am I indebted to Mr. J. D. Ogilby, Mr. Whitelegge, and several other gentlemen for specimens of worms which, though not new, were from new localities.

\section{Eudrilus (?) DUbIUs, n. sp.}

The largest (moderately contracted spirit) specimens measure 60 to $65 \mathrm{~mm}$. long, $4 \mathrm{~mm}$. broad, and comprise about 110 segments ; several smaller specimens comprising about 85 segments are about $45 \mathrm{~mm}$. long.

Colour pallid, except where as at the anterior extremity and in the dorsal region the bloodvessels showing through the thin integument give a red tinge; clitellum of a yellow hue. 
Body cylindrical, and of nearly uniform girth, but tapering slightly just near the extremities.

Prostomium pear-shaped, dividing the buccal ring for a little more than half its width; the buccal ring as wide as the following segments, which are more or less conspicuously tri-annulate.

Clitellum comprising three complete segments, xIV-XVI, and including more or less of XIII and XVII ; of xIII sometimes almost the whole of it ; of xvil only just the anterior margin, or enough to include the male pores, but in no specimen was the whole of it included; thick and complete all round, usually hiding both the setæ and the boundaries of the segments.

Setæ of the ordinary character, about $\cdot 39 \mathrm{~mm}$. long, with a slight enlargement at about $\frac{1}{3}$ from the free tip, in eight longitudinal rows, of which on each side two are ventral, one lateral, and one is dorsal ; the first row on each side about as far from the median ventral line as the second row is from the first; the interval between the second and third rows somewhat less than twice that between the first and second; the fourth row about midway between the median dorsal line and the third row, the interval between the third and fourth wider than that between the first and second, but not so wide as that between the second and third. From about segment XxI or XxII forwards the setæ of the second row on each side stand gradually successively closer to the corresponding setæ of the first row until on segment xvin the interval between the two rows has diminished to about half; on xvII the first and second setæ on each side not visible ; from xvI the second rows diverge again until at about segment XII the setæ stand at the ordinary distance apart.

The two male pores are on two slight elevations on segment xviI, not conspicuous, hardly noticeable without a lens, just dorsad of the first row of setæ. The two oviducal pores are on xIv, in front of and in line with the first seta on each side. Spermathecal apertures and dorsal pores not visible. Nephridiopores very distinct, a row on each side commencing after segment IV, close to the anterior margins of the segments, and a little ventrad of the third row of setæ. 
Alimentary canal : the buccal mass and pharynx occupy about five segments; the portions of the alimentary canal in vi VII and viII straight and thin-walled; a gizzard I have been unable to make out; in each segment from Ix to XIII the alimentary canal is globularly dilated and very vascular, less marked in xiII, (and slightly also in xIv and $\mathrm{xv}$ ) probably representing the calciferous glands though separate pouches on each side are not pinched off; inxvi it suddenly increases in calibre to form the sacculated large intestine which continues to the end of the body.

Genitalia : two pairs of small white racemose testes in segments $\mathrm{XI}$ and XII, attached to the posterior face of the mesenteries between $\mathrm{x}$ and $\mathrm{XI}$, and $\mathrm{XI}$ and $\mathrm{XII}$, on each side of the alimentary canal (1) ; the two vasa deferentia commencing with two pairs of ciliated funnels in $\mathrm{x}$ and $\mathrm{xI}$ immediately in front of the posterior mesenteries, and joining the short genital dıcts a little way from the prostates; the prostates are two small narrow bodies in xvir, transversely placed, the short duct of each coming off from the inner (lower) extremity, and joined about half the distance from the gland by the posterior portion of the vas deferens; just in front of the proximal extremity of the genital duct is a pair of small delicate sacs lying in contact with one another and with the inner portion of the prostate; when separated they are seen to be attached just in front of the genital duct; each of them contains two slightly curved penial setæ, one about $85 \mathrm{~mm}$. long, the free end faintly striate but not spinose or with the tip bifid, the other developing; the ovaries have the usual situation in XIII ; the oviducts commence opposite to them in the same segment and open to the exterior in the next one, and present nothing unusual; the spermathecæ I have so far been unable to discover.

(1) Following the example of Perrier I speak of these bodies and of similar ones in the other species described in this paper as testes. Their real nature I intend to investigate specially subsequently. If they are vesiculæ seminales both their situation (attached to the mesenteries) and their relation to the ciliated rosettes are remarkable, as each pair of the bodies is always in a different segment to the pair of rosettes receiving their products. 
The last pair of hearts is in segment XII ; in this and also in $\mathrm{x}$ and $\mathrm{xI}$ they are very large, and originate in part from the supraintestinal vessel in these segments. The segmental organs comprise a pair of coiled tubules in each of the segments but a few of the anterior ones.

Hab.-Sydney, Mulwala, N.S.W, ; Adelaide S. A. (possibly introduced).

It is uncertain whether this worm is indigenous, as so far I have had specimens only from gardens. Those from Mulwala, sent by Mr. Sloane, were from a garden to which at one time plants had been brought from Melbourne. It is a remarkable little worm, which as it has a pair of male pores on segment xvir, and I can find no spermathecæ of the ordinary character, is referred to Perrier's genus Eudrilus; but it differs in several points from any of the three or four species of this genus yet described, as for example in having no bursa copulatrix, and in not having the spermathecæ connected in a remarkable manner with the oviducts. At present I can identify neither a gizzard nor spermathecæ in any of my specimens. The distinction between intraclitellian and postclitellian is a very fine one indeed in the case of this species, as in none of my specimens is the segment which bears the male pores wholly included in the clitellum, though the pores themselves are more or less completely; so that while the worms are always unsatisfactorily postclitellian yet they are often not altogether satisfactorily intraclitellian.

\section{Cryptodrilus rubens, $\mathrm{n}$. sp.}

A good (spirit) specimen is $55 \mathrm{~mm}$. long, $4 \mathrm{~mm}$. wide ; comprising 114 segments. The pear-shaped prostomium divides the buccal ring for more than half its width.

Colour of the anterior portion of the body dark red, most noticeable in front of the girdle, in the posterior half of the body as well as on the under surface the colour much lighter. 
The girdle comprises three segments, $\mathrm{xIV}$ to $\mathrm{xVI}$, and is thick and complete all round, the setæ and intersegmental boundaries just visible.

Setæ of the ordinary shape, about $\cdot 45 \mathrm{~mm}$. long, in eight longitudinal rows, not in pairs ; first row on each side ventral, a little to one side of the median line, the second row also ventral, the third lateral, the fourth dorsal ; the first and second rows stand closer to each other than do the third and fourth; the interval between the third and fourth about equal to that between second and third, and about twice that between the first and second.

On xvirI a pair of conspicuous somewhat conical elevations marked with several circular groves; on the summit of each a small median papilla (perhaps only the everted terminal portion of the genital duct) on which are the male pores about in line with the second row of setæ; a second and third smaller and less conspicuous papillæ, one immediately in front, the other immediately behind the median one, each with a pore through which probably the penial setæ are extruded. Oviduct pores two on xIv. Spermatinecal pores not determinable. Dorsal pores absent. Nephridipores not visible.

Alimentary canal : the buccal mass and pharynx extend through about the first four segments; in vI and in vII a thin-walled globular portion either or both of which may perhaps be a gizzard ; calciferous glands in segments $\mathrm{x}$-xIII, the last pair very large and conspicuous; the intestine is quite narrow in the next two segments, while in xvI the large intestine suddenly commences, and continues throughout the rest of the body.

Genitalia: a single pair of testes only visible in XII, white racemose bodies independent of each other, attached to the posterior face of the mesentery between $\mathrm{XI}$ and $\mathrm{XII}$; an anterior pair possibly overlooked; ciliated rosettes in $\mathrm{x}$ and $\mathrm{xI}$; vasa deferentia not visible; prostates a pair of long narrow transverselydisposed bodies in xvin, sometimes folded on themselves, with a rather long much-bent duct coming off from near the inner (lower) end of the gland, gradually increasing in dianeter: the two 
ovaries have the usual situation in XIII ; the oviducts commence opposite them in the same segment and open to the exterior in xIV ; spermathecæ not visible. Lying beside each genital duct are two small sacs each containing two penial setæ about $\cdot 7 \mathrm{~mm}$. long gradually tapering to a fine point.

The last pair of hearts is in XII.

Segmental organs consisting of a pair of convoluted tubules in each of the segments with the exception of a few anterior ones.

Hab.-Mt. Wilson.

This interesting little worm is the only one with eight rows of setæ as yet forthcoming from this locality. When alive it resembles in appearance the small perichæte worms. So far I have been able to examine only a few small spirit specimens, a number of living specimens which I brought down after my last visit having unfortunately died before I could examine them. The spermathecæ and gizzard may have been overlooked, but so far I have not been able to find them.

\section{Perissogaster excavata, g. et sp. n.}

Three (spirit) specimens from the Hunter are $69 \mathrm{~mm} ., 195 \mathrm{~mm}$., and $250 \mathrm{~mm}$. (a softer specimen) long respectively, and $3 \mathrm{~mm}$., $13 \mathrm{~mm}$., $15 \mathrm{~mm}$. broad respectively, and comprise about 160 to 175 segments. A (spirit) specimen from the Hawkesbury is $334 \mathrm{~mm}$. long, $15 \mathrm{~mm}$. broad, and comprises 195 segments.

Prostomium wide, slightly depressed, ribbed by about five somewhat irregular longitudinal grooves, dividing the anterior annulus of the buccal ring. The latter is ribbed anteriorly by longitudinal grooves; superiorly and laterally it is marked with a slight transverse furrow at about $\frac{1}{3}$ from its anterior margin, incompletely dividing it into two annuli, and limiting the prostomium posteriorly. Segments broadest in the anterior region of the body, especially from about III to xvII ; the first three segments bi-annulate, II and III with the setæ towards the posterior margin 
of the anterior annuli; after iv for some distance the segments are tri-annulate with the setæ on the middle annuli, sometimes a faint indication of four annuli; behind the girdle the segments are narrower, tri-annulate, or sometimes bi-annulate, or quite posteriorly even smooth.

Setæ with a slight sigmoid flexure, about $0.7 \mathrm{~mm}$. long, with a slight enlargement about $\frac{1}{3}$ from the free end, the width again increasing slightly a little further back, then diminishing gradually a very little towards the imbedded end; in eight longitudinal rows forming two pairs, those of each outer pair a little further apart; the first row on each side about $2 \mathrm{~mm}$. from the median ventral line; the second row about $1 \mathrm{~mm}$. from the first; the third about $3 \mathrm{~mm}$. from the second; the fourth about $1.5 \mathrm{~mm}$. from the third; thus even the outer pairs are scarcely or only just lateral in position.

Clitellum absent in the smallest specimen; in the others commencing with the posterior annulus of xIII and taking in just the anterior margin or nearly the whole of xvirI, complete all round except for the fossa presently to be mentioned; in one specimen not so thick as to obscure the setæ and annular and intersegmental grooves, but in two other cases so thick as completely to do so. The ventral surface of segments XviII to xxI is thickened and flattened; and immediately behind the junction of XVII and XVIII but on the anterior annulus of XVIII and within the limits of the clitellum in two of them is a long narrow shallow depression or fossa, 8 or $9 \mathrm{~mm}$. long, and about $1 \mathrm{~mm}$. wide, placed transversely, and extending outwards nearly to the third row of setæ on each side, its margins thickened; on the anterior annuli of $\mathrm{xIx}, \mathrm{xx}$ and $\mathrm{xxI}$ similar but shallower depressions, or only the ends of these may be shewn, the intervening portions being more or less filled up, or marked only with a groove. The genital ducts are in segment xvIII, and judging from the situation of their proximal portions the first of these fossæo ought to carry the male pores near its extremities, but they are not visible externally in any of the specimens. The others appear to be of the nature 
of accessory copulatory organs, and also appear to carry indistinct pores. In the smallest specimen none (or perhaps the anterior one only) are visible. Thus two of the specimens are intraclitellian, but one of the others with a not fully developed girdle is not so.

Oviducal pores two, $2 \mathrm{~mm}$. apart, on either side the median line on XIv, and close to the posterior edge of the anterior annulus of this segment. Spermathecal pores two pairs, opening into the grooves between VII and VIII and VIII and IX, but situated on the anterior margins of VIII and Ix, in line with the first row of setæ, ventral in position.

Dorsal pores none; nephridiopores not discernible.

Alimentary canal : the buccal mass and pharynx occupy the first four segments, the pharynx anteriorly and superiorly coated with a glandular mass possibly salivary glands, bounded posteriorly by the first recognisable mesentery between IV and $\mathrm{v}$, the pharyngeal muscular bands very strong and numerous, those from the lateroposterior region arranged in four more or less complete circular rows, and passing through the first second or third or all three mesenteries to their insertions on the body walls in segments v, vi or VII ; in each of the segments just mentioned is a globular gizzard, the three gizzards and the pharynx counected by short pieces of œsophagus; from viII or IX to XIV the piece of intestine in each segment shews a very vascular globular dilatation, probably calciferous glands, though lateral diverticula seem not to be separated off; the large intestine commences suddenly in XVI, and though of larger calibre than the preceding portion, part of it being coiled in cork-screw fashion, this appears at first sight in a contracted worm to be much greater than it really is; unprovided with cæca.

Genitalia : two pairs of racemose testes (in the specimen dissected $5 \mathrm{~mm}$. long, by 1.5 wide) the anterior pair in Ix attached to the anterior surface of the mesentery between $\mathrm{Ix}$ and $\mathrm{x}$, the posterior pair in XII attached to the posterior surface of the mesentery between XI and XII, those of each pair quite independent of each other, one 
on either side of and arching above the alimentary canal ; ciliated rosettes two pairs in $\mathrm{x}$ and $\mathrm{xI}$, the whole vacant space in these two segments crammed with masses of fully formed and developing spermatozoa, apparently enclosed in very thin-walled sacs with the ciliated rosettes in each segment, but in too friable a condition to make out their relations thoroughly; prostates two, lobed masses each consisting of an anterior broader portion and a posterior narrow and longer portion, much bent on itself so as lie in two segments XVIII and XIX, or as on one side in xVIII only; a short duct comes off at about the junction of the broad and narrow portions of the gland; the posterior portions of the vasa deferentia were not visible: the two ovaries occupy the usual position in XIII ; the two oviducts commence opposite to them in the same segment and open to the exterior in the next segment; spermathecæ two pairs in VIII and Ix, stalked pear-shaped pouches opening anteriorly, each with a short wide cæcum placed anteriorly and which may be more or less bifid or even trifid at the free extremity.

The mesenteries after the first two or three complete ones as far back as that between XIII and XIV are enormously thick, and connected by interseptal bands; the posterior one of xIV is thinner, but much thicker than the succeeding ones.

There are hearts from $v$ to $x I I$, the last three pairs the largest, and these arise by two trunks, one from the dorsal vessel and one from a small supra-intestinal trunk; I could see no sub-nervian trunk, but in addition to the supra-nervian one there are two lateral vascular trunks in the anterior region of the body.

The segmental organs are apparently the small tufts of tubules attached to the cœlomic wall immediately in front of and behind the mesenteries, and most conspicuous in some of the anterior segments.

Hab.-Morpeth, and Hawkesbury River District, N.S.W.

This species cannot be referred to the genus Trigaster recently established by Mr. Benham for the reception of a West Indian 
earthworm with three gizzards, (1) because, among other points of difference, the latter has two pairs of male pores. For the specimens from the Hunter River I am indebted to the kindness of the Rev. K. A. Corner of Morpeth. For the opportunity of examining the single specimen from the Hawkesbury I have to thank Dr. Ramsay. I have had no information about the habits of these worms, which were probably obtained in both cases from the rich soil of the alluvial flats. (2).

\section{Pericheta exigua, n. sp.}

Three specimens (from the Blue Mts.) comprising 107-115 segments are about $6 \mathrm{~cm}$. long, and $3-3.5 \mathrm{~mm}$. broad; four others (from Randwick) comprising about 120 segments are from 4 to $5 \cdot 3 \mathrm{~cm}$. long, and 2.5-3 mm. broad; two others (from Manly Beach) of about the same dimensions, but both wanting the posterior portion of the body. Colour when alive bright red, lighter below. Prostomium nearly divides the buccal ring, the latter with a faint longitudinal groove in the median ventral line.

Clitellum of three complete segments, xIV-xvI, and slightly involving XVII in the lateral and dorsal regions, thick and complete all round in breeding worms so as to obscure setæ and dorsal pores.

Setæ commence with 20 per segment; this number may continue fairly constant, increasing a little way back to 21 or 22 , or in a few specimens quite in the posterior region it may increase even to about 30 per segment; there is a well-marked median ventral interval throughout devoid of setæ; a dorsal interval is less wellmarked though perceptible anteriorly, but in the hinder region of the body it is very little if any wider than the ordinary interval between two setæ.

(1) Quart. Jour. Micro. Sc. No. cv, August 1886, p. 94, pl. Ix, figs. 31-42.

(2) After this paper was read the Rev. K. Corner sent me an additional and larger supply of these worms, which came too late to be utilised in drawing up the above description. They will however enable me to supplement it on a future occasion, when figures of this and of several other of the species referred to in this paper, will be given. 
Male pores on papillæ on xvin, about in line with the 2nd or 3rd row of setæ on each side, or with the interval between them. Oviducal pores close together on xiv. Spermathecal pores a single pair, between viI and viII, corresponding with the interval between the 3rd and 4 th rows of setæ on each side.

Dorsal pores after segment $\mathrm{v}$.

Accessary copulatory structures comprise ventral thickening on $\mathrm{x}$ and $\mathrm{XI}$; and on some or all of XVI XVII XIX and $\mathrm{xx}$ there are other structures which are slightly different in the specimens from the three different localities: thus in Springwood specimens the ventral surface of xvII only, or of this and xIx, is thickened and marked with a somewhat elliptical fossa extending outwards on each side to the second seta, with a well-marked rim, and sometimes a raised central portion, and apparently with a pair of pores. In four Randwick specimens the fossæ are on xvII and $\mathrm{xx}$, while on XIx in front of the interval between first and second row of setæ there appears to be a pore. In two Manly specimens the fossa is on XVI, while on XVII and XIX there are two pairs of small papillæ with pore-like depressions, extending from the first to a little way beyond the second setæ.

Alimentary canal : the gizzard is in $\mathrm{v}$; four pairs of calciferous pouches in $\mathrm{x}$ to XIII with perhaps an additional one in $\mathrm{IX}$; the large intestine begins in xvi.

Genitalia: two pairs racemose testes attached to the anterior mesenteries of segments XI and XII ; two pairs ciliated rosettes in $\mathrm{x}$ and $\mathrm{xI}$; the prostates are white compressed bodies, incised superiorly so as to be 3-or 4-lobed, a lobe in each of segments $\mathrm{XVIII-Xx}$ or $\mathrm{xxI}$, the first and second lobes also partially divided by an incision from below, and from the groove so formed emerges the genital duct, the rest of which is bent in horse-shoe fashion, the limbs lying close together, and with the concavity of the bend looking backwards: the ovaries and oviducts have the usual situation and arrangements; the single pair of spermethecæ are in viII, opening anteriorly, each consisting of a large pearshaped sac with a distinct stalk, and a club-shaped cæcum only about half the length of the principal pouch. 
The last pair of hearts is in segment XII, the posterior three pairs much larger than the others.

Hab.-Springwood (Blue Mts.), Randwick and Manly Beach (near Sydney), N.S.W.

The specimens from these three localities agree very well except in regard to the accessory copulatory structures, which by themselves are of too variable a character to be relied on for purposes of classification. I therefore put them all in one species, though when more specimens are examined it may be possible to separate one or more varieties.

The only other worms with a single pair of spermathecæ that I have seen, were sent to me by Mr. T. G. Sloane from Mulwala on the Murray. They comprise six (spirit) specimens from 54-91 mm. long, and 2-3 mm. broad, consisting of from 88-125 segments. They are not sufficiently well-preserved for very satisfactory determination, nevertheless $I$ have been able to make out that they are closely allied to the above-described species but may be distinguished as

\section{Var. Murrayana,}

Differing from the typical form of $P$. exigua in having (1) the cæca of the spermathecæ very long, almost filiform but slightly dilated distally, much longer than the principal pouches, (2) the testes in IX and XII instead of in consecutive segments, (3) the prostates narrower, less incised; and the genital ducts shorter, thicker, and less markedly bent in horse-shoe fashion. There are also slight differences in the details of the accessory copulatory structures, in regard to which however the specimens differ among themselves.

Hab.-Mulwala, N.S.W.

Mr. Sloane tells me that this species is common in spring about the edges of lagoons and marshes after the floods in the Murray subside, but is scarce at other seasons when the ground becomes dry. 


\section{Pericheta monticola, n. sp.}

The two largest (contracted) spirit specimens comprising 124 and 151 segments are $12.7 \mathrm{~cm}$. and $15.5 \mathrm{~cm}$. long respectively, and $7 \mathrm{~mm}$. wide. The colour above is dark reddish brown, darkest in front of the clitellum (which is lighter) and for some distance behind it, and gradually becoming lighter posteriorly; below lighter, greyish. Prostomium divides the buccal ring almost completely.

Clitellum of three complete segments, xIV to xVI, and involving a portion of xiII or of xvII, or of both.

The number of setæ varies considerably in different regions of the body, and slightly in different specimens, so that I have not found two exactly alike in detail. The setigerous segments up to about XIII normally appear to have 16 setæ per segment, though after the first three or four there may be 17,18 or even 20 ; on the girdle this number may increase to 22 or 24 , or in one case 27 ; a few segments further back there may be 24-28; the number eventually increasing in the posterior region to 34 or 36 , or in one case 50. In front of the clitellum the intervals devoid of setæ are very broad in this species, the dorsal one especially so. Behind the girdle the ventral one narrows gradually but remains distinct throughout, whereas the dorsal one gradually narrows so much as to become hardly noticeable. The setæ from the anterior region are thicker and longer than those from further back.

The male pores are on papillæ on xviri, about in a line with 4th row of setæ. The oviducts open close together on a depression on xIv. The two pairs of spermathecal pores are between viI and viII, and viII and IX, just ventrad of the first row of setæ. The accessory copulatory structures not or scarcely noticeable except when the worms are breeding, comprise-a pair of slit-like depressions on a swollen area in the line of setæ but in the interval devoid of them on the ventral surface of Ix; a pair of 8-like swollen masses on ventral surface of $\mathrm{x}$, with four depressions perhaps pores; on the flattened 
ventral surface of xvil a pair of pores ventrad of the innermost setæ; a second pair on small papillæ just ventrad of the papillæ carrying the male pores ; a third pair on minute papillæ on XIX, in front of the line of setæ, and corresponding with the interval between the first and second setæ.

In other respects this species is like $P$. australis, except that there is an additional pair of calciferous pouches in XIII, and that the genital duct is differently disposed, as previously mentioned.

In a fresh specimen the calciferous pouches and the portion of the intestine in XIV presented a white and glistening appearance, the contents consisting chiefly of minute granules which effervesced on the addition of acid.

Hab.-Mt. Wilson.

I have already referred to this species in speaking of $P$. australis, from which, after having examined additional material, 1 find it to be readily distinguishable (1) by the greater breadth of the dorsal interval devoid of setæ in front of the clitellum and a corresponding decrease in the number of setæ, (2) the ventral position of the spermathecal apertures, (3) the presence of an additional pair of calciferous pouches, (4) the different position of the bend of the genital duct, (5) as well as apparently by accessory copulatory structures, which were absent in all the specimens of $P$. australis yet examined.

\section{Pericheta Canaliculata, $n$. $\mathrm{sp}$.}

Thirteen (spirit) specimens varying from $9 \mathrm{~cm}$. long and $8 \mathrm{~mm}$. broad to $14.5 \mathrm{~cm}$. long and $8 \mathrm{~mm}$. broad; number of segments from about 120-160. Body cylindrical, tapering just anteriorly, and more gradually for a considerable distance posteriorly. Colour even in spirit specimens purplish or reddish-brown, paler below. Prostomium dividing the buccal ring very slightly; marked anteriorly and inferiorly by several (three or more) irregular longitudinal markings; superiorly with a median longitudinal groove, continuing sometimes across the buccal ring, or not on to this, or 
on to the succeeding segments as far back as the first dorsal pore. It may then be present on all the succeeding segments of the body. Thus the grooving may be absent from all the first six or seven segments, or present on the first one and absent from the others up to about the twelfth segment, but from this backwards it is present in every one of the specimens, commencing at the dorsal pore on the anterior margin of the segment and terminating at the pore on its posterior margin, so that it may be said that all or the greater part of the body is marked in the median dorsal line by a longitudinal linear groove interrupted at the dorsal pores. In addition all the specimens show a similar but shallower and fainter median ventral grooving on the posterior half of the body, commencing at a variable distance (in one case at segment $\mathrm{xx}$ ) behind the girdle.

Segments in front of the girdle widest, usually bi-annulate.

Setæ on a conspicuous ridge just behind the annular groove, frequently the ridge not limited by grooves; a median dorsal and a median ventral interval devoid of setæ, the latter well-defined throughout, its bounding rows of setæ straight, between two and three times the width of the interval between two setæ, a little wider anteriorly; the dorsal interval at first very broad, sometimes but few dorsal setæ in this region, further back the interval is narrower, but throughout owing to gaps in the half-circles of setæ its bounding lines are very irregular and sinuous: the first two or three setigerous segments appear normally to have 16 setæ per segment, the next few 24 , increasing shortly to 34 , eventually increasing in the most posterior segments to about 50 per segment. The details are liable to considerable variation as not only are there gaps in the half-circles of setæ, but especially in the anterior dorsal region portions of the setigerous ridges disappear leaving the surface quite smooth; so that in a general way the pre-clitellar segments may be said to have any number of setæ from 14 to 38 , though after the first few the number 24 sometimes occurs pretty regularly; sometimes more setæ are visible on one side of a segment than on the other. 
Clitellum complete in one specimen; slightly developed and recognisable in two others; absent in all the rest; comprises five complete segments xiv to xviII, and in addition takes in small portions of XIII and XIX ; as the male pores are on XVIII the species is therefore intraclitellian.

Male pores on two prominent papillæ about $5 \mathrm{~mm}$. apart, in line with about the 5 th or 6 th rows of setæ, or with the interval between them; setæ not visible on the ventral surface between the pores. Oviduct pores two, in the interval devoid of setæ, on segment $\mathrm{xIV}$, close together, just in front of the line of setæ. Spermathecal pores three pairs, between segments vI and VII, VII and VIII, and VIII and Ix, about in line with the 5th row of setæ.

Dorsal pores after segment v. Nephridiopores not discernible.

No trace of any accessory copulatory structures.

The alimentary canal comprises a buccal mass and muscular pharynx with its strong pharyngeal muscles occupying the first four segments, a long piece of œsophagus several times bent on itself, of which a short anterior portion is in $\mathrm{v}$, and a much longer piece with the large gizzard in VI, the latter having immediately behind it the posterior mesentery of this segment, but pushing back it and the next two or three succeeding mesenteries which thus-in a contracted worm-come to lie close to each other, and causing a considerable displacement in these segments; in segments IX to $\mathrm{XV}$ the small intestine presents calciferous glands, the portions in these segments being very vascular, globularly dilated, internally shewing ridges, but distinct pouches are not pinched off; the portion in XVI is narrow, while in XVII the large intestine suddenly commences; this is without cæca, and being coiled in cork-screw fashion its apparent calibre is greater than it really is.

The first noticeable mesentery, thin and incomplete, is that between IV and $\mathbf{v}$; from about viII to $\mathbf{x V I}$ the mesentaries are somewhat thicker than elsewhere.

Genitalia: two pairs of testes in $\mathrm{XI}$ and $\mathrm{xII}$, small white bodies $(2.5 \mathrm{~mm}$. long, and about $1 \mathrm{~mm}$. wide in a specimen $12.5 \mathrm{~cm}$. 
long, in which the clitellum was not developed) adherent along their whole length to the posterior surfaces of the mesenteries between $\mathrm{x}$ and $\mathrm{XI}$, and $\mathrm{XI}$ and $\mathrm{xII}$, quite independent of each other, one on each side of and on a level with the intestine : two pairs of ciliated rosettes in $\mathbf{x}$ and $\mathbf{x I}$, in one specimen the whole width of the floor in each of these segments occupied by a white mass sending up a prolongation visible on each side of the intestine, consisting of spermatozoa apparently enclosed in a delicate sac along with the ciliated rosettes; in a second specimen there was a considerable mass of spermatozoa on each side in each segment but the ciliated rosettes appeared to be quite free, though if so it may have been accidental, or judging from the girdle in consequence of the cessation of the breeding function; prostates two, in segment xvIII, each consisting of a larger upper lobe, and a smaller lower one from which the prostatic duct comes off; this is joined at some distance from the gland by the posterior portion of the vas deferens; the genital duct then continues straight for some distance, but just its proximal portion is bent round sharply forming a small horse-shoe, the convexity of which looks inwards : ovaries two, in the usual position in XIII ; oviducts apparently not in any way remarkable; spermathecæ three pairs, opening anteriorly, in segments viI to Ix, shortly-stalked pear-shaped pouches, each with a very short but conspicuous club-shaped cæcum.

Attached to the posterior surface of the mesentery between XII and XIII, one on each side, in a position nearly corresponding with that of the two pairs of testes in XI and XII, and some distance above the ovaries, I found in both specimens dissected a pair of smooth white sacs, from their situation looking much like a third but rather larger pair of testes. From the difference in their contents however they have nothing to do with the genitalia. They showed only granules, granular cells, and encysted parasites. I have met with something similar in $P$. Barronensis, but at present I do not know what these bodies really are, as their symmetrical arrangement is remarkable if they are merely parasitic outgrowths. 
Segmental organs consist of a pair of conspicuous coiled tubules in each segment except the first two or three; each tubule consisting of three well-marked portions, a short and tolerably straight portion, an enlarged vesicular portion, and a long convoluted narrow distal portion. The last two pairs of hearts in XI and XII are very large.

Hab.-Mossman River, Cairns District, N.Q. (Macleay Museum).

This is a remarkable and interesting species, the study of which I intend to take up again later on. Notwithstanding that it is normally intraclitellian it cannot be referred to Megascolex Templ. (redefined by Beddard) from which it differs among other things in having fewer setæ, and spermathecæ provided with cæca. On the other hand except for the girdle its characters are paralleled in some or other of the numerous described species of Perichceta, and it should not in my opinion be placed in a genus separate from them. I am inclined to think that it will eventually be desirable to restrict the genus Perichata to the typical perichæte worms with complete circles of setæ and intestinal cæca, and to make a separate genus for the pleurochæte worms without cæca like the worm under consideration. At present I regard the latter as an example of what Beddard has already met with in Acanthodrilus, and as strengthening his view that Perrier's classification in so far as it relates to the separation of the Postclitelliani from the Intraclitelliani is too artificial to be ultimately retained.

\section{Pericheta Stirlingi, n. sp.}

Five (spirit) specimens from $10 \mathrm{~cm}$. to $20 \mathrm{~cm}$. long, $8-11 \mathrm{~mm}$. broad, comprising from about 130-140 segments. The anterior dorsal portion of the body much darker, but the colours are bleached by the spirit.

Prostomium depressed, concave below, with a median longitudinal groove, and a transverse one at about half the distance from its anterior margin; divides the buccal ring for about $\frac{3}{4}$ of its width. 
First two or three segments without annulations, after which as far back as the girdle they may be triannulate ; behind the girdle the segments are narrower and are tri- or they may be quadriannulate.

Setæ of the usual character, about $35 \mathrm{~mm}$. long, inconspicuous on the dorsal region making it difficult to count them ; somewhat less numerous on the anterior segments, apparently from 30 to 40 per segment; a well-defined ventral interval devoid of them, about thrice the width of the interval between two setæ; the dorsal interval very irregular owing to its bounding rows of setæ not being straight, and to the gaps in the rows of setæ in this region.

Clitellum in the largest specimen comprising segments XIV-XVII together with the posterior half of xIII except on ventral surface; complete all round; indicated in the others only by the darker colour of these segments.

Male pores on xvili, about in line with the interval between third and fourth rows of setæ on each side ; pores of oviducts two, close together, about $1 \mathrm{~mm}$. apart on xIV ; three pairs of spermathecal pores, lateral, about in line with 6 th row of setæ, between VI and vII, VII and VIII, VIII and Ix.

Accessory copulatory structures well developed; a pair of circular or elliptical papillæ at the junction of xvI and xvII, closer together than those further back, in line with the interval between first and second rows of setæ on each side; a second and third pairs at the junctions of xvIII with the preceding and succeeding segments, one immediately in front of, and the other immediately behind, and in line with the male pores; five additional pairs of small elliptical elevations similarly situated at the junctions of the following five segments; in the specimens without girdles either only the anterior ones, or more or fewer of them are only faintly indicated.

Alimentary canal: the muscular pharynx occupies about the first four segments ; a very short œsophagus and the large gizzard are in $\mathrm{v}$, the latter displacing the two mesenteries behind it and in 
this way occupying vi and part of vII ; in each segment from viII to XIV the alimentary canal shows a globular dilatation, very vascular, probably functioning as calciferous glands, though lateral diverticula are not visible ; the portions of the intestine in $\mathrm{XV} \cdot \mathrm{XVII}$. are very thin-walled; the large intestine suddenly commences in $\mathrm{xvIII}$, and is without cæca.

Mesenteries: a thin incomplete one between IV and $\mathrm{v}$, a complete but very thin one between $\mathrm{v}$ and $\mathrm{vI}$, the next one thicker, the following seven as far back as the one between XIII and XIV very much thicker, the remaining ones very thin.

Genitalia: two pairs testes, in $\mathrm{XI}$ and $\mathrm{xII}$, narrow elongate racemose or lobulated white bodies attached to the posterior faces of the mesenteries between $\mathrm{x}$ and $\mathrm{XI}$ and $\mathrm{XI}$ and XII, one on each side of the intestine, quite independent of each other; ciliated rosettes in $\mathrm{x}$ and $\mathrm{xI}$, quite free and unenclosed in any sacs (from other considerations the specimen dissected was evidently not breeding), the posterior portions of the vasa deferentia not discernible; prostates a pair of long narrow rather flat bodies transversely disposed in xvIII, with a thick short genital duct coming off from the inner (lower) end ; just in front and for some distance behind the genital duct the floor of the body shews white elevations, accessory copulatory glands: the ovaries occupy the usual position in XIII ; the oviducts not determinable the worm being in rather too soft condition; spermathecæ three pairs, in VII-IX, stalked pouches, opening anteriorly, the posterior pair the largest, each with a small but conspicuous club-shaped cæcum nearly as long as the stalk of the principal pouch.

The last pair of hearts is in XIII ; from vIII-XIII a second supraintestinal longitudinal vessel is apparent, from which in part arise the four posterior pairs of hearts. Very minute tufts of tubules attached to the colomic wall appear to represent the segmental organs.

As in $P$. canaliculata in the specimen dissected there was a pair of symmetrically-placed stalked bodies on the posterior surface of 
the mesentery between XII and XIII, not racemose and smaller than the testes, of which from their situation they look at first sight like a third pair.

Hab.-Lofty Ranges near Adelaide, S.A.

For specimens of this very distinct species, the first recorded from South Australia, I am indebted to Professor Rennie, and to Dr. Stirling from whose garden they came.

\section{Pericheta Raymondiana, n. sp.}

Two spirit specimens comprising 103 and 135 segments respectively, were 19 and $26 \mathrm{~cm}$. long, and 8 and $9 \mathrm{~mm}$. broad respectively. When alive evidently of a very dark red above, lighter below. The prostomium all but divides the buccal ring, is superiorly marked with a longitudinal median groove, and with a transverse one at a distance of about $\frac{1}{3}$ of the width of the buccal ring from its anterior margin; the buccal ring not grooved inferiorly in the median line.

Clitellum well developed in both specimens, the body much constricted in this region; comprises nearly five segments, XIII to $\mathrm{xVII}$, in one specimen not taking in the anterior portion of XIII and the posterior portion of xvil, but in the other except that their ventral portions were less modified both segments may be said to be included.

Male pores on small papillæ on xviII, corresponding with the interval between the first and second setæ on each side. Dorsad of, but contiguous and at right angles to each papilla is a ridgelike eminence running nearly across the breadth of the segment, but no pores are visible on it. There are accessory copulatory structures on the ventral portion of XVII and xVIII, consisting of ellipsoidal thickenings each with an obscurely-indicated pair of pores ; the ventral interval devoid of setæ in some of the segments in front of the girdle is also thickened. The two ovarial apertures are close together on an ellipsoidal area on xIv. The 
three pairs of spermathecal pores are between vi and VII, vil and vIII, VIII and Ix, in line with the second seta on each side. The dorsal pores commence after segment $\mathrm{v}$.

Setæ of the ordinary shape but with the sigmoid flexure not quite so marked as usual, less numerous, thicker and twice as long $(0.93 \mathrm{~mm}$.) and further apart in the anterior region; at first 28 per segment (sometimes 24) increasing posteriorly to about 36 ; a narrow space devoid of setæ in the median dorsal line, at first about twice the width of the interval between two setæ, but gradually diminishing posteriorly; in the median ventral line a slightly wider interval conspicuous throughout.

In regard to the divisions of the alimentary canal, the number and situation of the various reproductive organs, the vascular system, and the segmental tufts, this species sufficiently closely resembles $P$. austrina as not to call here for detailed description. The gizzard is in segment $\mathbf{v}$ as it is in that species, and not in vi as previously stated.

Nine mesenteries from the posterior one of vi to the posterior of XIV are very thick and muscular. Segments X and XI were crammed with masses of spermatozoa enclosed with the ciliated rosettes in each segment in a delicate membranous sac.

Hab.-Raymond Terrace, Hunter River, N.S.W.

With two specimens of this species I received several other perichæte worms, one at least of a different species, but too small and too soft for satisfactory determination at present; also a large number of specimens of Allolobophora turgida, all from the same neighbourhood, and for which I am indebted to the kindness of a lady.

\section{Pericheta Hamiltoni, n. sp.}

A good (moderately contracted) spirit specimen comprising 148 segments was $14.3 \mathrm{~cm}$. long, and $5 \mathrm{~mm}$. broad: three other specimens out of a number found dead after a flood in the Cudgegong River, less contracted and softer, were 28,30 and $35 \mathrm{~cm}$. long respectively and $6-8 \mathrm{~mm}$. wide ; the largest one comprising about 150 segments. 
Setæ of the ordinary shape, stouter, twice as long (about $0.7 \mathrm{~mm}$.) and further apart in the anterior region; on the first setigerous segments 16 per segment, increasing to 20 for a number of segments, while behind the girdle the number is from 28 to about 30 ; the dorsal interval at first very broad, about four times the width of the interval between two setæ, gradually diminishing until it is no broader than an ordinary interval; the ventral interval not quite so wide, noticeable throughout.

The male pores are on papillæ on xvıII, apparently also a second pair of papillæ on this segment but without pores (the large specimens have the ventral portion of XVII-XIX swollen and the male pores on circular papillæ); papillæ with pores on XVII and XVIII ; only indistinct swellings on $\mathrm{Ix}$ and $\mathrm{x}$.

In other respects this species is like $P$. austrina and requires no further description here.

\section{Hab.-Guntawang, N.S.W.}

Mr. A. G. Hamilton of Guntawang, who sent me specimens of this species, informs me that three of them were samples of some hundreds found dead in an anabranch of the Cudgegong River, in December 1886 after a flood, the first for fifteen years. Apparently during a succession of dry seasons the worms had betaken themselves to what, in wet seasons, is the bed of the anabranch, whence they had been dislodged, and drowned by the flood. The specimens sent had been dead some time before they were noticed, hence they are not in very good condition for examination; but though the papillæ carrying the male pores and the accessory copulatory structures are slightly different, they appear to belong to the same species as the other specimen which was dug out of the river-bank.

\section{Pericheta Wilsoniana, n. sp.}

Largest of eight (spirit) specimens $94 \mathrm{~mm}$. long, $4 \mathrm{~mm}$. broad; comprising about 120 segments. Clitellum of three complete segments, xIV-xvI, together with more or less of xvII, but in one case including $\mathrm{xVIII}, \mathrm{xIx}$ and part of $\mathrm{xx}$; this specimen therefore 
is intraclitellian. Setæ at first 20 per segment, further back usually 24 , and quite posteriorly sometimes about 28 ; ventral interval devoid of setæ conspicuous throughout, about twice the width of the interval between two setæ; dorsal interval at first wider than an ordinary interval, but posteriorly not so.

Two pairs of papillæ on xviII, and a pair of copulatory papillæ on XVII and on XIX ; on $\mathrm{x}$ a pair of rectangular raised areas with a groove between them, extending outwards to about 4th seta on each side.

There is apparently a fourth pair of calciferous pouches in xIII.

In other respects this species is like $P$. austrina.

Hab.-Mt. Wilson.

\section{Pericheta fecunda, n. $\mathrm{sp}$.}

Two (spirit) specimens from different localities are 74 and $65 \mathrm{~mm}$. long, 3.5 and $3 \mathrm{~mm}$. broad, and comprise 108 and 115 segments respectively. Body cylindrical, tapering slightly anteriorly, and more gradually posteriorly ; colour darker above, especially anteriorly; when alive an iridescent steel-blue. Prostomium nearly divides the buccal ring, the latter inferiorly marked with a median longitudinal groove.

Setæ for about the first three setigerous segments 20 per segment, increasing to 24 just about the clitellum, with 28 a little way behind it, and about 30 per segment in the posterior region. Sometimes a few more setæ are visible on one side of a segment than on the other. Ventral interval devoid of setæ noticeable throughout, about twice the width of the space between two setæ; the dorsal interval anteriorly a little wider than that between two setæ, posteriorly not noticeable.

Clitellum complete, comprising three entire segments XIV to XVI and slightly involving XIII and xvII (in one case about half).

Male pores on xvirI, about in line with the interval between first and second setæ on each side. Oviduct pores two, close 26 
together on xIv, in front of the line of setæ. Spermathecal pores four pairs, intersegmental from segments $\mathrm{v}$ to $\mathrm{Ix}$, in line with or slightly dorsad of the second row of setæ on each side.

Dorsal pores after segment IV. Nephridiopores not visible. The accessory copulatory structures are slightly different in detail in the two specimens; they comprise swollen areas with pits or pores on the ventral surface of $\mathrm{x}$ and $\mathrm{xI}$ (in one case circular and extending outward from the first to the sixth seta on each side), while the ventral surface of segments XvII to $\mathrm{xx}$ or $\mathrm{xxII}$ is much thickened, flattened, and some of these shew a tranisverse shallow depression, and a pair of indistinct pores.

In one of the specimens dissected the gizzard was in $\mathrm{v}$, calciferous pouches in $\mathbf{x}$-xIv, the large intestine commencing in $\mathbf{x v I}$, without cæca. Testes two pairs in IX and xII, ciliated rosettes in $\mathrm{x}$ and $\mathrm{XI}$, prostates two, in XVIII and XIX ; ovaries in XIII, spermathecæ four pairs, in segments vi to Ix, opening anteriorly, the club-shaped cæca nearly as long as the main sacs. The posterior pair of hearts is in xIII.

Hab.-Mt. Wilson, and Lawson, N.S.W. 


\section{$2 \mathrm{BHL}$ Biodiversity Heritage Library}

Fletcher, J. J. 1887. "Notes on Australian earthworms. Part III." Proceedings of the Linnean Society of New South Wales 2, 375-402.

https://doi.org/10.5962/bhl.part.29187.

View This Item Online: https://www.biodiversitylibrary.org/item/21749

DOI: https://doi.org/10.5962/bhl.part.29187

Permalink: https://www.biodiversitylibrary.org/partpdf/29187.

\section{Holding Institution}

MBLWHOI Library

Sponsored by

MBLWHOI Library

\section{Copyright \& Reuse}

Copyright Status: NOT_IN_COPYRIGHT

This document was created from content at the Biodiversity Heritage Library, the world's largest open access digital library for biodiversity literature and archives. Visit BHL at https://www.biodiversitylibrary.org. 